\title{
Madagascar's nascent locally managed marine area network
}

\author{
Taylor Lee Mayol
}

\section{ABSTRACT}

Since 2004, the creation of locally managed marine areas (LMMAs) in Madagascar has exponentially increased, highlighting the need for improved information sharing between communities and between support organizations. Until recently, however, these LMMAs operated in relative isolation, with little communication or coordination between LMMA community associations. Madagascar's first national LMMA forum was held to address this need in June 2012 in the village of Andavadoaka, on Madagascar's southwest coast. The forum brought together 55 community members from 18 LMMAs throughout Madagascar, representing a total of 134 villages. A principle outcome of this meeting was the formation of a national LMMA network named MIHARI, a Malagasy acronym that translates into 'local marine resource management'. The nascent MIHARI network is an informal network that was inspired by the success of the LMMA Network in the Indo-Pacific region. MIHARI aims to facilitate peer-to-peer learning amongst coastal communities, improve communication, raise the profile and expand the use of the LMMA approach and serve as a unified lobbying platform for the interests of Madagascar's traditional fishers. The creation of MIHARI represents a significant development towards uniting community-led approaches to conservation in Madagascar and highlights the significant role LMMAs can play in marine conservation on a national scale. This is of particular significance in Madagascar, a country with little capacity or financial resources to oversee large-scale marine conservation efforts, a problem compounded by both the vast coastline and geographical isolation of many fishing communities. Madagascar's new LMMA network is leading the way for coastal community conservation in the western Indian ocean and aims to serve as the basis for a wider regional LMMA network.

\section{RÉSUMÉ}

Depuis 2004, la mise en place d'Aires Marines Gérées Localement (AMGL) à Madagascar suit une augmentation exponentielle, soulignant la nécessité d'améliorer le partage d'informations entre les communautés et les organisations partenaires. Néanmoins, jusqu'à récemment, ces AMGL opéraient de façon isolée en ne profitant que d'une faible communication ou coordination entre les différentes AMGL et les associations communautaires. Afin de combler ce besoin, le premier forum national sur les AMGL à Madagascar s'est tenu en

\author{
Blue Ventures Conservation \\ U.K. \\ E-mail: mayol.taylor@gmail.com
}

juin 2012 dans le village d'Andavadoaka. Le forum a rassemblé 55 représentants de communautés provenant de 18 AMGL différentes de Madagascar, représentant un total de 134 villages. Un des aboutissements phares de ce rassemblement fut la création d'un réseau national d'AMGL, dénommé MIHARI, un acronyme malgache qui se traduit par 'gestion locale des ressources marines'. Ce réseau naissant MIHARI est un réseau informel qui s'inspire du succès de son homologue dans la région IndoPacifique. MIHARI a pour objectif de faciliter l'enseignement entre pairs au sein des communautés côtières, d'augmenter la communication, d'accroitre la visibilité, d'encourager et de faciliter le recours à I'approche AMGL et de servir de plateforme commune de lobby dans l'intérêt des pêcheurs traditionnels de Madagascar.

La création de MIHARI représente un développement conséquent en vue de l'unification des approches communautaires pour la conservation à Madagascar, et met en lumière le rôle important que jouent les AMGL dans le domaine de la conservation marine à l'échelle nationale. Cela a une importance primordiale à Madagascar, un pays où les ressources en termes de capital et de compétences sont insuffisantes pour la supervision d'initiatives de conservation marine à grande échelle ; une problématique elle-même exacerbée par l'étendue des zones côtières et l'isolation géographique de nombreuses communautés de pêcheurs. Le nouveau réseau d'AMGL de Madagascar fait figure de chef de file pour la conservation communautaire dans I'océan Indien et compte bien servir de socle pour un réseau AMGL régional.

\section{LOCALLY MANAGED MARINE AREAS}

Fishing communities have been managing marine resources in a number of ways for hundreds of years. However, in recent decades traditional fisheries (sensu FAO No date) around the world have come under increasing pressure from the effects of both indirect and direct threats, such as global climate change (Cinner et al. 2012), population growth (Harris et al. 2012) and overfishing (Harris 2011). The result has been that fishing communities are finding that once abundant resources are dwindling. Locally managed marine areas (LMMAs) have emerged as effective solutions to challenges of small-scale fishery management in tropical low-income countries (Govan et al. 2008, Obura and Samoilys 2011). LMMAs are defined as "areas of near-shore waters and coastal resources that are largely or wholly man- 


\section{vOLUME 8 ISSUE 2

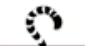 NOVEMBER 2013 MADAGASCAR 5,8 CONSERVATION \& DEVELOPMENT}

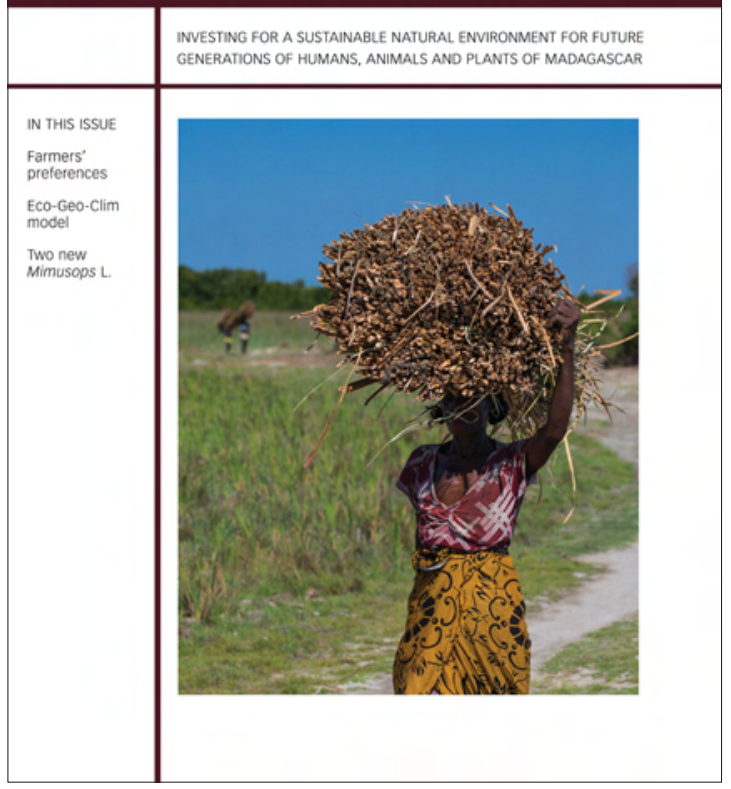

Madagascar Conservation \& Development is the journal of Indian Ocean e-Ink. It is produced under the responsibility of this institution. The views expressed in contributions to MCD are solely those of the authors and not those of the journal editors or the publisher.

All the Issues and articles are freely available at http://www.journalmcd.com

Contact Journal MCD

info@journalmcd.net for general inquiries regarding MCD funding@journalmcd.net to support the journal

Madagascar Conservation \& Development Institute and Museum of Anthropology University of Zurich

Winterthurerstrasse 190

$\mathrm{CH}-8057$ Zurich, Switzerland

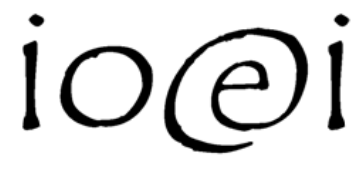

Indian Ocean e-Ink

Promoting African Publishing and Education www.ioeink.com
Missouri Botanical Garden (MBG)

Madagascar Research and Conservation Program BP 3391

Antananarivo, 101, Madagascar 
aged at a local level by the coastal communities, land-owning groups, partner organisations, and/or collaborative government representatives who reside or are based in the immediate area" (Govan et al. 2008: 2). The main impetus for the creation of LMMAs is a "community desire to maintain or improve livelihoods, often related to perceived threats to food security or local economic revenue" (Govan 2009: 86).

Using LMMAs, communities are able to tailor and blend traditional and modern management practices to best suit their needs (Govan 2009). This community-based approach has proven to be a cost-effective, resilient and a more socially acceptable alternative to traditional top-down management of natural resources in places such as southwest Madagascar (Harris 2007). In addition, LMMAs have shown promise at addressing coastal poverty and issues of food security by mitigating overfishing and implementing temporary and permanent reserves (Govan 2009, Obura and Samoilys 2011). Although Govan (2009) suggests caution when implementing income-generating projects within LMMAs and cite a lack of evidence of success, some LMMAs have succeeded in incorporating supplementary livelihoods projects, such as aquaculture farms (Robinson and Pascal 2009, Harris 2011). The LMMA approach also places community members at the forefront of decision-making, ensuring that those who are most affected by conservation decisions are responsible for those choices and the subsequent enforcement of any resource regulation (Gutiérrez et al. 2011). This means LMMAs also build institutional capacity through developing managerial and problem solving skills in community leaders, thus improving local adaptability to climate change. The LMMA approach ensures greater incentive and support for conservation projects than traditional top-down approaches (Obura and Samoilys 2011) by utilising local management structures that better understand the nuanced relationship between marine resource users and their environment.

Communities and their supporting non-governmental organisation (NGO) partners have created thriving national and regional networks in the Indo-Pacific region; over 600 villages participate in 420 LMMAs (Tan and Parras 2011), collectively known as the LMMA Network. This network has proved invaluable for information sharing and scaling up of the LMMA approach and has provided inspiration for the further expansion of LMMAs as a resource management tool.

\section{THE EXPANSION OF LMMAS IN MADAGASCAR}

Sustainable fishery management in Madagascar is a key development priority and vital to ensuring food security for coastal communities (Le Manach et al. 2012). Marine fisheries contribute $7 \%$ of GDP and $20 \%$ of export earnings and play a significant role in food security and job creation (FAO 2008). Additionally, the sea plays a central role in the cultural heritage of geographically isolated, traditional fishing communities along Madagascar's $5,500 \mathrm{~km}$ coastline. However, Madagascar is politically volatile and economically unstable (Ploch and Cook 2012, Randrianja 2012a, b), with decreasing indicators of social well - being (World Bank 2011) and inadequate capacity and financial resources to effectively oversee complete management of its traditional fisheries (Harris 2011). Community-based conservation is often the most effective substitute for, or supplement to, national fisheries management. Furthermore, it builds heavily upon Madagascar's goal, known as former President Marc Ravalomanana's 2003
Durban Vision, to triple its protected areas through the effective involvement of local communities in natural resource management (Norris 2006).

Since 2004, Madagascar has witnessed an exponential increase in the number and popularity of LMMAs. The development of Madagascar's first LMMA followed the launch of the first temporary octopus fishery closure in 2004 in the village of Andavadoaka in southwest Madagascar (Harris 2007). The initial seven-month closure of a designated octopus fishing site, led by the local fishing community with guidance from the Wildlife Conservation Society and Blue Ventures, allowed octopus stocks to recuperate and resulted in a noticeable increase in catch upon reopening (Harris 2007, Obura and Samoilys 2011). The quick pay-off from this initial closure allowed fishers to see the immediate benefits of resource management interventions and quickly led to the spread of the temporary octopus closure model to surrounding communities. Today, seven years of data (2004-2010) proves that octopus closures improve fisher income through a $461 \%$ increase in median recorded catches per closure and lead to an enhancement in catch per unit effort (CPUE) of up to $120 \%$ following the reopening (Benbow and Harris 2011). The data also demonstrate that the economic benefits of the closures outweigh any potential negative effects (Benbow and Harris 2011).

As the number of temporary closures surrounding Andavadoaka grew with repetition and replication, the need for a broad management body to regulate and coordinate closure activities became apparent. In 2006 this led to the creation of the Velondriake LMMA and its governing body, the Velondriake Association. Velondriake, meaning 'to live with the sea', covers approximately $680 \mathrm{~km}^{2}$ and encompasses 25 villages (Peabody and Jones 2012).

The temporary octopus closure model was quickly recognised as an effective tool for shifting community attitudes towards participation in conservation (Langley et al. 2006, Cinner et al. 2009a), and in 2007 was supported and promoted by the Projet d'appui aux communautés des pêcheurs (PACP), a government project funded by the African Development Bank. PACP worked along Madagascar's southwest coast, from south of Toliara to Morombe, to fund local NGOs committed to working with communities to establish new marine reserves. PACP and local NGOs used Andavadoaka as a training base for communities interested in learning about the temporary octopus fishery closure model, and soon communities throughout the southwest adopted the approach. Now, as a result of community exchange trips to the southwest, and with support from Conservation International, closures have spread to northern Madagascar and internationally to the Mauritian island of Rodrigues. The spread of the closure model led many communities throughout Madagascar to emulate the Velondriake LMMA and create their own LMMAs. Several LMMAs also grew organically, according to each area's specific needs.

Peer-to-peer learning has proven highly effective at initiating new conservation initiatives, passing on local conservation knowledge (Obura and Samoilys 2011) and maintaining momentum within the communities responsible for implementing LMMAs. However, the ability of LMMA leaders to communicate regularly and exchange information remained limited to isolated instances; there was no single structure used to facilitate discussion and most collaboration amongst LMMAs 
was restricted to intermittent communication between NGO partners or between LMMAs supported by the same NGO. The rapid geographic expansion of LMMAs throughout the country, combined with the lack of regular opportunities for LMMA coordination and cooperation, spurred discussions amongst partner NGOs about the need for an inaugural national LMMA forum.

\section{FROM FORUM TO NATIONAL NETWORK}

Madagascar's first national LMMA forum took place in Andavadoaka in June 2012. Fifty-five representatives from 18 of Madagascar's LMMAs attended the forum, which was hosted by Blue Ventures and the Velondriake Association. The 18 LMMAS in attendance represented approximately 134 villages from Madagascar's coastal regions, including Atsimo-Andrefana, Menabe, Melaky, Analanjirofo and Diana. Additionally, eight NGOs and LMMA partner institutions were in attendance: Blue Ventures, Cellule des Océanographes de I'Université de Tuléar, which is Madagascar's National Marine Institute, Cetamada, Conservation International, Honko, the Wildlife Conservation Society, and the World Wide Fund for Nature.

The forum provided a platform for Madagascar's LMMA representatives to discuss common challenges their communities face in managing marine resources sustainably, and share the innovative solutions many have developed to overcome these challenges. Participants gave comprehensive overviews of their LMMA's governing structure, management techniques, activities within the LMMA, conservation project implementation strategies, and accomplishments and challenges. LMMA representatives discovered that nearly all LMMAs had previously implemented either a permanent or temporary reserve, or both.

A second part to the forum was organised in Toliara, directly following the trip to Andavadoaka. In Toliara, the forum included government representatives from all of the relevant regional agencies, as well as two representatives of the Ministry of Fisheries in Antananarivo and one representative from Madagascar's protected areas system (SAPM). This meeting provided an opportunity for dialogue and information exchange between the LMMA leaders and government agencies. Most importantly, it allowed LMMA representatives to discuss the challenges they face in local management and identify opportunities for improved government support.

The forum ultimately led representatives to recognise the importance for continued communication and the significance of a united LMMA coalition. This led them to establish Madagascar's first national LMMA network, named MIHARI, with the goal of creating a structure to continue dialogue. MIHARI is an acronym that translates into 'local marine resource management'. Informal networks like MIHARI have proven effective at facilitating information sharing and peer-to-peer learning amongst coastal communities in other regions (Obura and Samoilys 2011), and MIHARI seeks to emulate the efforts made by the LMMA Network in the Indo-Pacific region.

The growing MIHARI network will provide opportunities for further collaboration amongst Madagascar's LMMAs and continue to raise awareness among regional and national government officials of the scale of the LMMA movement, and the scope of marine area currently under local management. This united front of LMMAs will be able to better voice concerns and ideas and leverage their interests concerning national poli- cies and official marine protected areas. The creation of the network also marks a significant addition to the work undertaken by Madagascar National Parks to promote local marine management thus far, and represents a notable step towards Madagascar's ambitious goal to triple the coverage of its protected areas (Norris 2006, Harris 2011).

\section{DINA}

The creation of MIHARI is particularly beneficial considering the high level of commonality across Madagascar's LMMAs shown at the forum. The LMMAs represented almost universally use dina to enforce marine management resolutions. Dina are local laws based upon a traditional social code (Cinner et al. 2009b). Although dina are created and enforced by communities (ibid), they can be recognised by regional courts, enabling dina to be administered as law (Rakotoson and Tanner 2006, Andriamalala and Gardner 2010). During the forum, LMMA leaders specifically requested support from regional authorities for assistance with enforcement of dina, but highlighted the importance of community-based decision-making and consensus before any consultation with public authorities on dina-related matters. Community leaders agreed they face difficulties with providing adequate evidence to regional courts in litigation cases and proposed that public authorities provide technical support and capacity building to members of the community involved in the creation and extension of dina; this would ensure more effective application in the future.

While dina are typically focused on specific local issues (Andriamalala and Gardner 2010), certain themes, such as banning the use of destructive fishing gears like beach-seine nets, were common across all LMMAs represented. Despite this, the proposal of a 'national dina' was deemed impractical by government authorities during the Toliara forum. According to the officials, the creation of such a dina would essentially amount to the creation of new fisheries laws, an extensive process that must occur through national government channels. Government representatives did suggest, however, that if certain destructive fishing practices are widely banned by multiple LMMAs it could provide a strong basis for an official nationwide ban. This would expand on sub-regional government bans in existence, such as Arrêté 18680/2006, which bans the use of mosquito netting for fishing in Antongil Bay (Government of Madagascar 2006).

\section{ONGOING DEPENDENCE ON EXTERNAL SUPPORT}

During the LMMA forum, the leaders also discussed ongoing reliance on support from partner NGOs, particularly in terms of financial and technical assistance, as well as for the development of viable alternative livelihood activities. Participants expressed the desire to diversify sources of income, but pointed to the inaccessibility of private seafood sector collectors and the need for assistance from NGOs in identifying and evaluating the feasibility of potential activities, providing training and capacity building, and connecting communities to international markets. For example, in the Velondriake LMMA, a communitybased holothurian aquaculture project is beginning to generate significant income for local communities (Harris 2011). However, the project remains reliant on the regular field presence of Blue ventures as well as a successful partnership with a seafood collection company that provides juvenile sea cucumbers from 
an industrial factory and purchases and exports the adults to lucrative Asian markets (Harris 2011).

\section{LEGAL CLARIFICATIONS}

At the Toliara forum, community representatives united to request clarification from regional authorities on a number of issues. Firstly, they raised concerns over potential overlap of community marine resource management and future mining and oil exploration permits. Government officials identified exploitation of Madagascar's natural resources as part of the country's development strategy, but underlined the importance of integrating local management efforts into national zoning plans and protected areas systems to avoid future conflict.

Leaders also highlighted the continued lack of clarity regarding the ways in which community groups can legally generate income in order to sustainably finance LMMA initiatives. The implications of community associations' status as a non-profit entity (as stipulated by Malagasy Law 60 133) remain ambiguous. In some instances, government officials have interpreted this non-profit status to mean that community associations cannot perform income-generating activities and therefore cannot fundraise, aside from charging LMMA member fees. This presents a significant barrier to the long-term financial sustainability of LMMAs; NGO project funding cycles are inherently short-term, and community associations must eventually inherit LMMA operating costs. This matter will need further clarification, as it appears that there is not currently a common understanding of how LMMA associations are allowed to generate income under Malagasy law.

\section{CONCLUSION}

The creation of the MIHARI network is a major milestone towards more effective community-based marine conservation in Madagascar. The establishment of MIHARI sets the stage for further replication of the LMMA approach, as well as more frequent dialogue amongst coastal fishing communities. Moving forward, a top priority for partner organizations will be continued support for the nascent MIHARI network through the formation of a robust and functional communications plan and the standardisation of social and ecological evaluation methodologies. Additionally, improving internal management capacity of community associations, as well as communication between communities, government representatives and private sector stakeholders will be crucial to ensure the long-term sustainability of management efforts, as well as a gradually decreasing role of NGOs and other supporting organisations.

\section{REFERENCES}

Andriamalala, G. \& Gardner, C. J. 2010. L'utilisation du dina comme outil de gouvernance des ressources naturelles: leçons tirés de Velondriake, Sud-ouest de Madagascar. Tropical Conservation Science 3, 4: 447-472.

Benbow, S. and Harris, A. 2011. Managing Madagascar's octopus fisheries. Proceedings of the Workshop on Octopus Cyanea Fisheries, 5-6 April 2011, Toliara. Blue Ventures Conservation, London. Available at <http://www.blueventures.org/conservation-reports/managingmadagascars-octopus-fisheries-proceedings-of-the-workshop-onoctopus-cyanea-fisheries.html>

Cinner, J., Fuentes, M. M. P. B. and Randriamahazo, H. 2009a. Exploring social resilience in Madagascar's marine protected areas. Ecology and Society 14, 1: \#41. <http://www.ecologyandsociety.org/vol14/iss1/ art41/>
Cinner, J. E., Wamukota, A., Randriamahazo, H. and Rabearisoa, A. 2009b. Toward institutions for community-based management of inshore marine resources in the Western Indian Ocean. Marine Policy 33, 3 489-496. (doi:10.1016/j.marpol.2008.11.001)

Cinner, J. E., McClanahan, T. R., Graham, N. A. J., Daw, T. M., Maina, J., Stead, S. M., Wamukota, A., Brown, K. and Bodin, Ö. 2012. Vulnerability of coastal communities to key impacts of climate change on coral reef fisheries. Global Environmental Change 22, 1: 12-20. (doi:10.1016/j. gloenvcha.2011.09.018)

FAO Food and Agriculture Organisation of the United Nations. No date. FAO Glossary. <http://www.fao.org/fi/glossary/> accessed 19 October 2013.

FAO Food and Agriculture Organisation of the United Nations. 2008. Fishery Country Profile, The Republic of Madagascar.

Govan, H. 2009. Status and potential of locally-managed marine areas in the Pacific Island Region: meeting nature conservation and sustainable livelihood targets through wide-spread implementation of LMMAs. SPREP. WWF. World Fish-Reefbase. CRISP. Munich Personal RePEC Paper No. 23828. Available at <http://mpra.ub.uni-muenchen.de/23828/1/ MPRA_paper_23828.pdf>

Govan, H., Aalbersberg, W., Tawake, A. and Parks, J. 2008. Locally-Managed Marine Areas: A Guide for Practitioners. The Locally-Managed Marine Area Network. USP. Suva, Fiji. Available at <http://www.Immanetwork. org/files/Immaguide.pdf>

Government of Madagascar 2006. Arrêté №18680/2006 du 30 octobre 2006, portant interdiction de I'utilisation de senne de plage et d'engins de pêche confectionnés à l'aide de tulle moustiquaire dans la baie d'Antongil. Ministère de l'Agriculture, de l'Elevage et de la Pêche, Government of Madagascar, Antananarivo.

Gutiérrez, N. L., Hilborn, R. and Defeo, O. 2011. Leadership, social capital and incentives promote successful fisheries. Nature 470: 386-389. (doi:10.1038/nature09689)

Harris, A. 2007. "To live with the sea": Development of the Velondriake community-managed protected area network, Southwest Madagascar. Madagascar Conservation \& Development 2, 1: 43-49.

Harris, A. 2011. Out of sight but no longer out of mind: a climate of change for marine conservation in Madagascar. Madagascar Conservation \& Development 6, 1: 7-14. (doi:10.4314/mcd.v6i1)

Harris, A., Mohan, V., Flanagan, M. and Hill, R. 2012. Integrating family planning service provision into community-based marine conservation. Oryx 46, 2: 179-186. (doi:10.1017/S0030605311000925)

Langley, J., Harris, A. and Nihalani, N. 2006. The 2004-5 census of Andavadoaka, southwest Madagascar. Blue Ventures Conservation, London. Available at <http://www. blueventures.org/conservationreports/the-2004-2005-census-of-andavadoaka-southwest-madagascar.html>

Le Manach, F., Gough, C., Harris, A., Humber, F., Harper, S. and Zeller, D. 2012 Unreported fishing, hungry people and political turmoil: the recipe for a food security crisis in Madagascar? Marine Policy 36, 1: 218-225. (doi:10.1016/j.marpol.2011.05.007)

Norris, S. 2006. Madagascar defiant. Bioscience 56, 12: 960-965. (doi:10.1641/0006-3568(2006)56[960:MD]2.0.CO;2)

Obura, D. O. and Samoilys, M. A. 2011. Marine conservation successes in Eastern Africa. CORDIO East Africa, Mombasa. Available at <http:// cordioea.net/storage/status-report-2011/Samoilys_2011-Marine\%20 conservation\%20successes\%20in\%20Eastern\%20Africa.pdf>

Peabody, S. \& Jones, B. 2012. Plan d'Aménagement et de Gestion de la NAP Velondriake. Unpubl. Report. Blue Ventures Conservation, London.

Ploch, L. and Cook, N. 2012. Madagascar's Political Crisis. Congressional Research Service, Report for Congress. Available at <http://www.fas. org/sgp/crs/row/R40448.pdf>

Randrianja, S. (ed.). 2012a. Madagascar, le Coup d'État de Mars 2009. Karthala Editions, Paris.

Randrianja, S. 2012b. "Love me tender - transition vers où?" Madagascar Conservation \& Development 7, 1: 9-16. (doi:10.4314/mcd.v7i1.3)

Rakotoson, L. and Tanner, K. 2006. Community-based governance of coastal zone and marine resources in Madagascar. Ocean and Coastal Management 49, 11: 855-872. (doi:10.1016/j.ocecoaman.2006.08.003) 
Robinson, G. and Pascal, B. 2009. From Hatchery to Community Madagascar's First Village-Based Holothurian Mariculture Programme. Secretariat of the Pacific Community. Fiji. Available at <http:// www.spc.int/DigitalLibrary/Doc/FAME/InfoBull/BDM/29/BDM29_38_ Robinson.pdf>

Tan, W. and Parras, T. 2011. The Locally-Managed Marine Area Network 2010 Annual Report: Defining our Future. The Locally-Managed Marine Area Network. Available at <http://www.Immanetwork.org/files/ annual_reports/LMMA2010AR.pdf>

World Bank 2011. Madagascar economic update: aid effectiveness during political instability - a look at social sectors. The World Bank, Washington, DC. Available at <https://blogs.worldbank.org/africacan/ files/africacan/madagascar_economic_update_march_17.pdf accessed> 